\title{
PENGARUH PROSES REKRUITMEN TERHADAP KINERJA ORGANISASI DI PT. ANGKASA PURA I (PERSERO) BANDARA INTERNASIONAL MAKASSAR
}

\author{
HASTUTI $^{1}$, BUDISETIAWATI ${ }^{2}$, IHYANI MALIK ${ }^{3}$ \\ 1) Mahasiswa Jurusan Ilmu Administrasi Negara Unismuh Makassar \\ 2) Dosen Jurusan Ilmu Administrasi Negara Unismuh Makassar \\ 3) Dosen Jurusan Ilmu Administrasi Negara Unismuh Makassar
}

\begin{abstract}
The study aims to determine how much influence the process recruitmen the performance of the organization. This types of research is carried out with the kind of quantitative descriptive type. In taking a random sample was simple (random sampling). The data was analyzed by linear regression and correlation with the help of statistical program spss 16. Hypothesis test shadow that the variables of process recruitmen $(t)=0,751$ with sig value of 0,355 for the value of the signature that gained more than 0,05 indicates that the value of $(t)$ obtained is significant. This means that the process recruitmen variables $(x)$ effect on performance of the organization (y) then Ho are accepted. The are fore the outhers accepted hypothesis.
\end{abstract}

Keyword:The culture of process recruitmen, organizational, performance

\begin{abstract}
ABSTRAK
Penelitia ini bertujuan untuk mengetahui seberapa besar pengaruh proses rekruitmen terhadap kinerja organisasi. Jenispenelitian iniadalah jenis kuantitatif dilakukan dengan tipe penelitian survey.Dalam mengambil sampel dilakukan secara data pengaruh proses rekruitemen dikumpul dengan menggunakan instrument berupa questioner, observasi terhadap beberapa responden. Data tersebut dianalisis secara statistik regresi linear dan korelasi dengan bantuan statistic program SPSS release 16. Uji hipotesis menunjukkan bahwa variable proses rekruitmen $(t)=0,751$ dengan nilai sig sebesar 0,000 karena nilai dari sig yang diperoleh lebih dari 0,355 maka menunjukkan bahwa $(\mathrm{t})$ yang diperoleh tersebut signifikan. Hal ini berarti bahwa variable proses rekruitmen (X) berpengaruh terhadap kinerja organisasi (Y) maka Ho diterima. Oleh karena itu hipotesis yang diajukan penulis diterima.
\end{abstract}

Kata kunci:proses rekruitmen, kinerja organisasi 


\section{PENDAHULUAN}

Pengelolaan sumber daya manusia (SDM) merupakan hal yang penting dalam pencapaian tujuan.Umumnya pimpinan perusahaan mengharapkan kinerja yang baik dari masing-masing karyawan dalam mengerjakan tugastugas yang diberikan oleh perusahaan.perusahaan menyadari bahwa sumber daya manusia (SDM) merupakan modal dasar dalam proses pembangunan perusahaan bahkan nasional, oleh karena itu kualitas SDM senantiasa harus dikembangkan dan diarahkan agar tercapai tujuan yang telah ditetapkan oleh perusahaan. Adapun aktivitasaktivitas manajemen sumber daya manusia initerdiri dari: Perencanaan sumber daya manusia, pengadaan, pengarahan, pengembangan, pemeliharaan dan pemberhentian. Hal ini ditujukan agar perusahaan dapat mengelola sumber daya manusia yang baik secara efektif dan efesien.Menurut undang-undang no. 13 tahun 2004 tentang Ketenagakerjaan pasal 52 ayat d menyebutkan pengusaha tidak boleh memberi kewajiban kerja yang bertentangan dengan ketertiban umum, kesusilaan, dan peraturan perundang-undangan yang berlaku. Sebuah kontrak kerja, menurut pasal 54 ayat 1 undang-undang no 13 tahun 2003, harus memuat: nama, Alamat perusahaan, dan jenis perusahaan. Nama, jenis kelamin, umur dan alamat pekerja Jabatan atau jenis pekerjaan. Tempat pekerjaan. Salah satu aktivitas dalam pengelolaan sumber daya manusia adalah rekrutmen. Rekruitmen adalah suatu proses pengumpulan sejumlah pelamar yang memiliki kualifikasi yang sesuai dengan yang dibutuhkan perusahaan untuk dipekerjakan didalam perusahaan (Malthis 2001). Adapun manfaat dari rekruitmen adalah memiliki fungsi sebagai "The Righ Man On The Right Place", dimana hal ini menjadi pegangan bagi para manajer dalam menempatkan tenaga kerja yang ada diperusahaan PT. Angkasa Pura I (persero) merupakan perusahaan yang bergerak dibidang jasa pengelolaan bandara, dimana bandara Internasional Sultan Hasanuddin merupakan salah satu bandara yang termasuk dalam 
pengelolaan PT. Angkasa Pura I (persero). Sumber daya manusia yang handal dan kompeten merupakan faktor mengungkit untuk keunggulan bersaing PT. Angkasa Pura I (persero), sehingga pengembangan kompetensi sumber daya manusia merupakan salah satu faktor kunci keberhasilan untuk pencapaian visi dan misi PT. Angkasa Pura I (persero).Sejalan dengan visi misi dan strategi perusahaan untuk menjadi perusahaan kelas dunia dibidang jasa kebandaraudaraan, perlu diterapkan upaya yang lebih fokus dalam pengembangan SDM secara konsisten dan terusmenerus..Menurut (Handoko:2008) menyatakan bahwa proses rekruitmen saat ini memiliki beberapa istilah populer diantaranya job Analisis, job description, job specification, job evaluation, job classification. Uraiannya sebagai berikut:Job Analysis (analisis jabatan) Analisis jabatan merupakan prosedur untuk menentukan tanggung jawab dan persyaratan, keterampilan dari sebuah pekerjaan dan jenis orang yang akan
diperiksa.Job description (uraian jabatan) Menurut Yoder dalam Moekjizat (2010) menyatakan bahwa uraian jabatan adalah mengiktisarkan fakta-fakta yang diberikan oleh analisis jabatan dalam susunan yang sistematis. Uraian jabatan merupakan garis-garis besar yang ditulis dan dimaksudkan untuk memberikan keterangan tentang fakta-fakta yang penting dari jabatan yang diperlukan.

Job specification (persyaratan jabatan) persyaratan pekerjaan adalah catatan mengenai syaratsyarat orang yang minimum harus dimiliki untuk menyelesaikan suatu pekerjaan suatu pekerjaan dengan baik (Moekjizat:2010).Job evaluation (penilaian jabatan) Menurut Moekjizat 2010 penilaian jabatan adalah kegiatan yang dilakukan guna membandingkan nilai dari suatu jabatan dengan nildengan jabaai dari jabatan lainnya.Job classification (penggolongan jabatan) menurut Moekjizat $2010 \quad$ adalah pengelompokkan jabatan-jabatan yang memiliki nilai yang sama.Nawawi

(2008:167) 
mengemukakan terdapat empat sikap yang berbeda dalam lingkungan organisasi atau perusahaan dalam melakukan rekruitmen. Ke empat sikap dalam rekruitmen tersebut dapat dijabarkan sebagai berikut:

Sikap pasif tanpa diskriminasi Sikap ini merupakan sikap para eksekutif dilingkungan organisasi atau perusahaan untuk meniadakan perbedaan dan memberlakukan secara sama dalam mengangkat, menggaji dan memberikan promosi bagi para calon dan para pekerja. Rekruitmen berdasarkan perbedaan, rekruitmen ini dilakukan secara aktif untuk mengelompokkan para pelamar, dengan hanya menerima kelompok tertentu. Rekruitmen berdasarkan prioritas, rekruitmen ini dilakukan dengan mendahulukan atau memprioritaskan kelompok tertentu.Rekruitmen dengan penjatahan, rekruitmen dilakukan dengan menetapkan jatah untuk kelompok tertentu.

Berdasarkan keempat sikap tersebut, maka keputusan dalam rekruitmen dan pengaturan staff sebaiknya dilakukan berdasarkan kasus masing-masing.Dengan demikian ras dan jenis kelamin yang sering kali menjadi masalah, dapat dijadikan salah satu faktor saja dalam pengambilan keputusan untuk menerima atau menolak calon pelamar.Keputusan harus berdasarkan kepada kombinasi semua faktor yang ada, dengan harus mengutamakan hasil skor (nilai) tes sebagai usaha dalam memprediksi kemampuan calon sebelum diterima.

Menurut Sastrohadiwiryo (2002: 162) rekruitmen merupakan masalah penting dalam pengadaan tenaga kerja, oleh karena itu, dalam melaksanakan rekruitmen perusahaan harus mempertimbangkan beberapa hal penting yang menjadi dasar perekrutan tenaga kerja yaitu: Rekruitemn dilakukan sesuai dengan tujuan perusahaan yang telah ditetapkan. Rekruitmen dilakukan sesuai dengan peraturan-peraturan perusahaan yang telah ditentukan. Rekruitmen dilakukan dengan cara yang benar dan sesuai prosedur perekrutan perusahaan. Rekrutmen dilakukan untuk memenuhi kebutuhan setelah diketahui specificasi jabatan atau pekerjaan karyawan yang diperlukan, maka 
harus ditentukan sumber-sumber penarikan. Sumber penarikan calon karyawan bisa berasal dari internal dan eksternal.Menurut Hendri Simamora (1997:212), rekruitmen (Recruitmen) adalah serangkaian aktifitas mencari dan memikat para pelamar kerja dengan motivasi, kemampuan, keahlian, dan pengetahuan yang diperlukan guna menutupi kekurangan yang di identifikasikan dalam perencanaan kepegawaian.

Menurut Simamora (1997:221) ada beberapa point penting proses rekruitmen:penyusutan strategi untuk merekrut, Didalam penyusutan strategi ini, departemen sumber daya manusia bertanggung jawab dalam menentukan kualifikasi-kualifikasi pekerjaan, bagaimana karyawan akan direkrut dimana dan kapan.Pencarian pelamar-pelamar pekerja, Setelah rencana dan strategi perekrutan disusun, aktivitas perekrutan sesungguhnya bisa berlangsung, melalui sumber-sumber perekrutan yang ada. Banyak atau sedikitnya pelamar dipengaruhi oleh usahausaha dari pihak perekrut didalam menginfrmasikan lowongan, salah satunya adanya ikatan kerjasama yang baik antara perusahaan dengan sumber-sumber perekrutan eksternal seperti sekolah, universitas.Penyisihan pelamarpelamar yang tidak cocok atau penyaringan, setelah lamaranlamaran diterima, haruslah disaring guna menyisihkan individu yang tidak memenuhi syarat kualifikasikualifikasi pekerjaan. Didalam proses ini memerlukan perhatian besar khususnya untuk membendung diskualifikasi karena alasan yang tidak tepat, sehingga dalam prose ini dibutuhkan kecermatan dari pihak penyaring.Pembuatan kumpulan pelamar, kelompok pelamar (applicant pool) terdiri atas individuindividu yang telah sesuai dengan criteria yang telah ditetapkan oleh perekrut dan merupakan kandidat yang layak untuk posisi yang dibutuhkan. Mangkunegara (2006) menyatakan kinerja dapat didefinisikan sebagai hasil kerja secara kualitas dan kuantitas yang dapat dicapai oleh seseorang pegawai dalam melaksankan tugas sesuai dengan tanggungjawab yang 
diberikan kepadanya. evalusi kinerja adalah penilaian yang dilakukan secara sistematis untuk mengetahui hasil pekerjaan karyawan dan kinerja organisasi.Dharma mendefinisikan kinerja sebagai sesuatu yang dikerjakan, produk atau jasa yang dihasilkan seseorang atau kelompok orang. pengertian tersebut melihat kinerja dari dua sisi yaitu dari sisi individu dan dari organisasi. Ukuran kinerja yang terakhir ini sudah mendekati ukuran ideal karena selain ukuran keuangan juga diukur aspek non keuangan. Dalam metode pengukuran ini terdapat empat perspektif yang beda yaitu :Perspektif keuangan, yaitu pengukura kinerja keungan yang mengarah kepada perbaikan, perencanaan, implementasi, dan pelaksanaan strategi. Perspektif pelanggan, yaitu menilai kinerja berdasarkan kepuasaan pelanggan atas produk atau jasa yang bernilai lebih bagi konsumen. Perspektif operasional, yaitu menilai kinerja berdasarkan inovasi, operasi dan layanan purna jual. Perspektif pembelajaran dan pertumbuhan, yaitu mengukur kinerja berdasarkan kemampuan pegawai, mencakup tingkat kepuasan pegawai, kemampuan system informasi, motivasi, pembelajaran dan keserasian individu perusahaan. Keban (2004:183) Kinerja organisasi adalah menggambarkan sampai seberapa jauh satu kelompok telah melaksanakan semua kegiatan pokok sehingga mencapai visi dan misi institusi. Penelitian ini akan memggunakan konsep pengukuran kinerja organisasi hanya dari aspek perspektif pelanggan, yang menilai kinerja organisasi berdasarkan kepuasan pelanggan atas pelayanan, produk, dan jasa yang bernilai lebih bagi pelanggan. yang meliputi; 1) kecepatan, 2) layanan, dan 3) nilai. (Furtwengler2002). Ukuran ini menjadi semakin penting dalam mencapai dan mempertahankan keunggulan bersaing. Keempat alat ukur kinerja organisasi yang fokus pada pelanggan menurut Furtwengler, (2002) dapat dijelaskan sebagai berikut :1) Kecepatan, dalam hal ini adalah kemampuan setiap karyawan dalam memberikan pelayanan terhadap para pelanggan atau nasabah, baik pelanggan internal 
maupun pelanggan eksternal yang sesuai dengan Standard Operating Procedure (SOP). 2) Layanan, adalah layanan yang diberikan oleh setiap karyawan sesuai dengan jenis pekerjannya yang diberikan pada semua pelanggan baikinternal maupun ekternal akan sangat mendukung kecepatan dan kualitas pelayanan. 3) Nilai, adalah setiap pelanggan menginginkan nilai layanan yang cepat dan berkualitas sesuai dengan harapan pelanggan.

\section{METODE PENELITIAN}

$\begin{array}{rcr}\text { Waktu } & \text { penelitian dilakukan } \\ \text { selama dua bulan karena dalam } \\ \text { pengambilan } & \text { data } & \text { penulis }\end{array}$
menggunakan kuesioner, observasi, dan dokumentasi. Penelitian ini dilakukan pada PT. angkasapura I (PERSERO) bandara internasional hasanuddin yang merupakan BUMN yang dikelola jasa kebandarausahaan yang berlokasi dijalan airpot kecamatan mandai kabupaten Maros, sulawesi selatan.Ditinjau dari jenisnya, penelitian ini menggunakan penelitian kuantitatif, dimana pada dasarnya metode penelitian kuantitatif menggunakan pendekatan pengukuran atau numeric terhadap masalah yang hendak diteliti dan juga pengumpulan data dan analisa data.Berangkat dari jenis penelitian ini, tipe yang digunakan pada penelitian ini yaitu survey. Penelitian survey adalah penelitian yang mengaambil sampel dari satu populasi dan menggunakan kuesioner sebagai alat pengumpul data yang pokok.

Populasi adalah seluruh data yang menjadi perhatian kita dalam suatu ruang lingkup dan waktu yang kita tentukan.Jadi populasi berhubungan dengan data PT. angakasa pura I bandara internasional hasanuddin bukan manusianya. Kalau setiap manusia memberikan suatu data, maka banyaknya atau ukuran populasi akan sama dengan banyaknya manusia. yang menjadi populasi pada penelitian ini adalah pegawai PT. angkasa pura I bandara internasional hasanuddin makassar sebanyak 210 orang. Sampel adalah sebagian dari populasi yang diambil dengan menggunakan cara-cara tertentu (Margono,2010). Teknik pengumpulan data pada penelitian ini 
adalah observasi, Penelitian ini menggunakan pendekatan kuantitatif. Analisa data dilakukan setelah data primer dan data sekunder terkumpul.

HASIL DAN PEMBAHASAN

$$
\text { Sejarah PT Angkasa Pura } 1
$$

(Persero) sebagai pelopor pengusahaan kebandar udaraan secara komersial di Indonesia bermula dari perusahaan negara $(\mathrm{PN})$ angkasa pura kemayoran yang dibentuk pada tanggal 20 februari 1962 dengan peraturan pemerintah (PP) Nomor 33 tahun 1962. Tugas pokoknya adalah pengelolaan dan pengusahaan bandar udara, Kemayoran Jakarta yang saat itu merupakan satu-satunyabandar udara internasional yang melayani penerbangan dari dan ke luar negeri selain penerbangan domestik.

Dalam perkembangannya, untuk lebih memperluas cakupan kerja mengelola bandar udara lain di wilayah Indonesia, berdasarkan PP Nomor 21 tahun 1965 PN Angkasa Pura Kemayoran berubah nama menjadi Perusahaan negara(PN) angkasa pura sejak tanggal 17 Mei 1965. Selanjutnya berdasarkan PP
Nomor 37 tahun 1974, status badan hukum perusahaan diubah menjadi Perusahaan Umum (Perum).Dengan ditutupnya bandar udara internasional kemayoran sejak tanggal 1 Oktober 1985, seluruh kegiatan operasi perusahaan dialihkan ke bandar udara soekarnohatta.Untuk mengatur pembagian wilayah pengelolaan bandar udara, berdasarkan PP Nomor 25 tahun 1987, sejak tanggal19 Mei 1987 Perum Angkasa Pura berubah nama menjadi

Perum Angkasa Pura I bersamaan dengan dibentuknya Perum Angkasa Pura II yang khusus bertugas mengelola bandar udara soekarno-hatta dan halim perdanakusuma. Selanjutnya, berdasarkan PP Nomor 5 Tahun 1992, bentuk perusahaan umum (Perum) diubah menjadi perseroan Terbatas (PT) yang sahamnya dimiliki sepenuhnya oleh Negara Republik Indonesia sehingga namanya menjadi PT Angkasa Pura I (Persero) dengan Akta Notaris Muhani Salim, SH tanggal 3 Januari 1993 dan telah memperoleh persetujuan menteri kehakiman 
dengan keputusan Nomor C2470.HT.01.01 Tahun1993 tanggal 24 April 1993 serta diumumkan dalam berita negara republik indonesia nomor 52 tanggal 29 Juni 1993 dengan tambahan berita negara republik perubahan anggaran dasar perusahaan terakhir adalah berdasarkan keputusan rapat umum pemegang saham tanggal 14 Januari 1998 dan telah diaktakan oleh notaris Imas Fatimah, SH Nomor 30 tanggal 18 September 1998. Perubahan anggaran dasar tersebut telah mendapat pengesahan dari menteri kehakiman republik indonesia Nomor: C2-25829. HT.01.04 Tahun 1998 tanggal 19 November 1998 dan dicantumkan dalam berita negara republik indonesia nomor 50 tanggal 22 Juni 1999 dengan tambahan berita negara republik indonesia nomor $3740 / 1999$.

PT Angkasa Pura I (Persero) yang selanjutnya disebut angkasa pura airports bertekad mewujudkan perusahaan berkelas dunia yang profesional. Angkasa pura airports yakin dapat melakukan yang terbaik dengan memberikan pelayanan keamanan, keselamatan, dan kenyamanan berstandar internasional bagi para pelanggan.

Sejarahangkasa pura airports sebagai pelopor pengusahaan kebandarudaraan secara komersial di indonesia bermula dari kunjungan kenegaraan Presiden Soekarno ke amerika Serikat untuk bertemu dengan presiden John F Kennedy. setibanya di tanah air, Presiden soekarno menegaskan keinginannya kepada menteri perhubungan dan menteri pekerjaan umum agar lapangan terbang di indonesia dapat setara dengan lapangan terbang di negara maju.

Tak lama kemudian, pada tanggal 15 November 1962 terbitlah Peraturan Pemerintah (PP) Nomor 33 Tahun 1962 tentang Pendirian Perusahaan Negara (PN) Angkasa Pura Kemayoran. Tugas pokoknya adalah untuk mengelola dan mengusahakan pelabuhan udara kemayoran di jakarta yang saat itu merupakan satu-satunya bandar udara internasional yang melayani penerbangan dari dan ke luar negeri selain penerbangan domestik.

Setelah melalui masa transisi selama dua tahun, terhitung sejak 20 
Februari 1964 PN angkasa Pura polonia - Medan, Juanda - Surabaya, kemayoran resmi mengambil alih Sepinggan-Balikpapan, dan Sultan secara penuh aset dan operasional pelabuhanudara kemayoran jakarta dari pemerintah. tanggal 20 Februari 1964 itulah yang kemudian ditetapkan sebagai hari jadi angkasa pura airports.

Pada tanggal 17 Mei 1965, berdasarkan PP Nomor 21 tahun 1965 tentang perubahan dan tambahan PP Nomor 33 Tahun 1962, PN angkasa pura kemayoran berubah nama menjadi PN angkasa pura, dengan maksud untuk lebih membuka kemungkinan mengelola bandar udara lain di wilayah Indonesia.

organisasi di PT. angkasa pura I Hasanuddin - Ujungpandang, kemudian bergabung dalam pengelolaan PN Angkasa Pura. Selanjutnya, berdasarkan PP nomor 37 tahun 1974, status badan hukum perusahaan diubah menjadi perusahaan umum (Perum).

$\mathrm{HO}=$ Tidak ada pengaruh antara proses rekruitmen terhadap kinerja organisasi di PT. Angkasa Pura I (PERSERO) Bandara Internasional Makassar $\mathrm{H} 1=$ Ada pengaruh antara proses rekruitmen terhadaap kinerja organisasi di PT. Angkasa Pura I (PERSERO) Bandara Internasional Hasanuddin.

(PERSERO) bandara internasional hasanuddin. Secara bertahap, pelabuhan udara ngurah rai - bali, halim perdanakusumah - jakarta, 
Tabel 1

Akumulasi frekuensi proses rekruitmen

\begin{tabular}{|c|c|c|c|}
\hline \multicolumn{4}{|c|}{ Penyusunan Strategi Untuk merekrut } \\
\hline No & Pernyataan & $\begin{array}{l}\text { Rata-rata } \\
\text { skor }\end{array}$ & Rata-rata \% \\
\hline 1 & $\begin{array}{l}\text { Tentang penyusunan strategi untuk } \\
\text { merekrut }\end{array}$ & 3,25 & $81,25 \%$ \\
\hline \multicolumn{2}{|r|}{ Rata-rata skor dan rata-rata $\%$} & 3,25 & $81,25 \%$ \\
\hline \multicolumn{4}{|c|}{ Pencarian pelamar } \\
\hline No & Pernyataan & $\begin{array}{l}\text { Rata-rata } \\
\text { skor }\end{array}$ & Rata-rata \% \\
\hline 1 & $\begin{array}{l}\text { Tentang pencarian pelamar-pelamar } \\
\text { kerja }\end{array}$ & 3,20 & $75,5 \%$ \\
\hline \multicolumn{2}{|r|}{ Rata-rata skor dan rata-rata \% } & 3,20 & $75,5 \%$ \\
\hline \multicolumn{4}{|c|}{ Penyisihan pelamar-pelamar } \\
\hline No & Pernyataan & $\begin{array}{l}\text { Rata-rata } \\
\text { skor }\end{array}$ & Rata-rata \% \\
\hline 1 & $\begin{array}{l}\text { Tentang penyisihan pelamar-pelamar } \\
\text { yang tidak cocok }\end{array}$ & 3,15 & $78,75 \%$ \\
\hline \multicolumn{2}{|r|}{ Rata-rata skor dan rata-rata $\%$} & 3,15 & $78,75 \%$ \\
\hline \multicolumn{4}{|c|}{ Pembuatan kumpulan pelamar } \\
\hline No & Pernyataan & $\begin{array}{l}\text { Rata-rata } \\
\text { skor }\end{array}$ & Rata-rata \% \\
\hline 1 & Tentang pembuatan kumpulan pelamar & 3,25 & $60,25 \%$ \\
\hline \multicolumn{2}{|r|}{ Rata-rata skor dan rata-rata $\%$} & 3,25 & $60,25 \%$ \\
\hline
\end{tabular}


Tabel 2

Akumulai frekuensi kinerja organisasi

\begin{tabular}{|c|c|c|c|}
\hline \multicolumn{4}{|c|}{ Kecepatan } \\
\hline No & Pernyataan & $\begin{array}{l}\text { Rata-rata } \\
\text { skor }\end{array}$ & Rata-rata \% \\
\hline 1 & Tentang kecepatan & 3,29 & $85,75 \%$ \\
\hline \multicolumn{2}{|r|}{ Rata-rata skor dan rata-rata $\%$} & 3,29 & $85,75 \%$ \\
\hline \multicolumn{4}{|c|}{ Layanan } \\
\hline No & Pernyataan & $\begin{array}{l}\text { Rata-rata } \\
\text { skor }\end{array}$ & Rata-rata \% \\
\hline 1 & Tentang layanan & 2,50 & $40,75 \%$ \\
\hline \multicolumn{2}{|r|}{ Rata-rata skor dan rata-rata $\%$} & 2,50 & $40,75 \%$ \\
\hline \multicolumn{4}{|c|}{ Nilai } \\
\hline No & Pernyataan & $\begin{array}{l}\text { Rata-rata } \\
\text { skor }\end{array}$ & Rata-rata \% \\
\hline 1 & Tentang nilai & 3,20 & $80,75 \%$ \\
\hline \multicolumn{2}{|r|}{ Rata-rata skor dan rata-rata $\%$} & 3,20 & $80,75 \%$ \\
\hline
\end{tabular}

Sumber data: hasil kuesioner 2016 
Berdasarkan pada tabel 1 diatas yang merupakan rekapitulasi dari kedua penjabaran yang telah dipaparkan dapat diketahui penyusunan strategi untuk merekrut di PT, Angkasa pura I Bandara Internasional Hasanuddin setuju.dengan melihat rekapitulasi yang menunjukkan nilai rata-rata skor dan rata-rata persentase $3,25(81,25$ persen) dapat disimpulkan bahwa mengenai penyusunan strategi dalam pengaruh proses rekruitmen di PT. Angkasa Pura I Bandara Internasional Hasanuddin termasuk dalam kategori setuju. Hal ini menandakan bahwa penyusutan strategi untuk merekrut pelamar berkategori ragu-ragu karena dilihat dari rekapitulasi responden mengenai kualifikasi-kualifikasi pekerjaan dengan rata-rata skor atau rata-rata persentase 2,84 atau 71,0 persen, hasil responden mengenai dimana karyawan akan direkrut dengan rata-rata skor atau rata-rata persentase 3,21 atau 80,25 persen sedangkan hasil responden mengenai kapan pelamar akan direkrut dengan skor rata-rata atau rata-rata persentase
3,18 atau 79,5 persen. Ini menyatakan bahwa penyusunan strategi untuk merekrut pelamar di PT. Angkasa pura I Bandara Internasional Hasanuddin berkategori ragu-ragu.

Berdasarkan pada tabel 1 diatas yang merupakan akumulasi dari ketiga penjabaran yang telah dipaparkan dapat diketahui bahwa pencarian pelamar-pelamar kerja dinilai berkategori setuju. Hal ini dapat dilihat dari akumulasi yang menunjukkan nilai rata-rata skor 3,20 $(75,5 \%)$ dapat disimpulkan bahwa mengenai pencarian pelamar-pelamar kerja di PT. Angkasa pura I Bandara Internasional hasanuddin berkategori setuju. Hal ini menandakan bahwa pencarian pelamar-pelamar kerja ini berkategori setuju karena dilihat dari rekapitulasi responden mengenai ikatan kerjasama yang baik antar perusahaan memperoleh rata-rata skor atau rata-rata persentase 3,5 atau 78,75 persen, hasil responden mengenai ikatan kerjasama dengan sekolah ratarata skor atau rata-rata persen 3,03 atau 75,75 persen, sedangkan mengenai ikatan kerjasama dengan 
universitas rata-rata skor atau rata-rata persentase 3,12 atau 78 persen. Ini menyatakan bahwa pencarian pelamarpelamar kerja di PT. Angkasa pura I(PERSERO) Bandara Internasional

Tanggapan responden mengenai penyisihan pelamar-pelamar yang tidak cocok atau penyaringan didominasi dengan jawaban penyisihan dengan memperoleh taanggapan sebanyak 23 orang atau sebesar 7,36 persen, sangat penyisihan memperoleh tanggaapan sebaanyak 7 orang atau sebanyak 2,24 persen, sedangkan kurang penyisihan memperoleh tanggapan sebanyak 2 orang atau 1,64 persen. Dengan nilai rata-rata skor 3,15 atau rata-rata persentase 78,75 persen, dapat disimpulkan bahwa tanggapan responden mengenai penyisihan pelamar-pelamar yang tidak cocok atau penyaringan tergolong setuju. Ini menyatakan bahwa penyisihan pelamar-pelamar yang tidak cocok atau penyaringan termasuk dalam kategori setuju.

Berdasarkan pada tabel diatas yang merupakan akumulasi dari kedua penjabaran yang telah dijelaskan dapat diketahui bahwa pembuatan kumpulan pelamar di PT. Angkasa pura I(PERSERO) Bandara Internasional Hasanuddin Makassar di nilai sangat setuju. Hal dapat dilihat dari akumulasi penjabaran nilai rata-rata skor dan rata-rata persentase $3,32 \quad(60,25$ persen).

Berdasarkan pada tabel 2 diatas yang merupakan rekapitulasi dari ketiga indikator kinerja organisasi jika dinilai dari kecepatan sangat setuju, layanan berkategori setuju, sedangkan nilai berkategori sangat setuju. Hal ini dapat dilihat dari rata-rata persentase dari ketiga indikator kinerja organisasi dimana indikator kecepatan dengan rata-rata skor 3,29 atau rata-rata persentase 85,75 persen, layanan dengan rata-rata skor 2,50 atau ratarata persentase 40,75 persen sedangkan nilai dengan rata-rata skor 3,20 atau rata-rata persentase 80,75 persen. 


\section{Tabel 2}

\section{Olahan Data Regresi dan Korelasi}

\begin{tabular}{|c|c|c|c|c|c|}
\hline \multirow{2}{*}{ Model } & \multicolumn{2}{|c|}{$\begin{array}{l}\text { Unstandardized } \\
\text { Coefficients }\end{array}$} & \multirow{2}{*}{\begin{tabular}{|c|}
$\begin{array}{r}\text { Standardiz } \\
\text { ed Coefficients }\end{array}$ \\
Beta
\end{tabular}} & \multirow{2}{*}{$\mathrm{T}$} & \multirow{2}{*}{$\begin{array}{l}\text { S } \\
\text { ig. }\end{array}$} \\
\hline & B & $\begin{array}{l}\text { Std. } \\
\text { Error }\end{array}$ & & & \\
\hline (Constant) & $\begin{array}{r}19.4 \\
18\end{array}$ & 5.286 & & $\begin{array}{r}3 . \\
674\end{array}$ & 000 \\
\hline $\begin{array}{l}\text { REKRUTME } \\
\text { NT }\end{array}$ & $\begin{array}{r}.25 \\
0\end{array}$ & .124 & .351 & $\begin{array}{r}2 . \\
021\end{array}$ & 003 \\
\hline $\begin{array}{l}R=0,351 \\
R 2=0123\end{array}$ & & & $\begin{array}{l}\text { Fhit }=4,085 \\
\text { Sig }=0,03\end{array}$ & & \\
\hline
\end{tabular}

Sumber : data diolah dengan spss 
Hasil olahan data regresi disajikan persamaan regresi sebagai berikut:

$\mathrm{Y}=19,418+\mathrm{X}=0,250$

Dari hasil persamaan regresi yang telah diuraikan diatas maka dengan nilai 19.418 adalah jumlah dari degresion residual, koefisien $\mathrm{X}$ $=0,250$ menunjukkan bahwa rekruitmen dengan kinerja organisasi berpengaruh positif. Nilai standardized yang error 5.286 dan .124. nilai beta .351 standardized coefficient, nilai test (T) 3,674 dan 2.021 sedangkan nilai sig .000 dan .003. dengan kata lain bahwa dengan pelaksaan rekruitmen maka akan mempengaruhi peningkatan kinerja organisasi.

Kemudian dapat dilakukan pengujian parsial variabel (rekruitmen) terhadap organisasi yang dapat diuraikan sebagai berikut: Regresi linear sederhana. Model ini digunakan untuk menguji pengaruh proses rekruitmen terhadap kinerja organisasi.

\section{KESIMPULAN}

Berdasarkan hasil analisis dan pembahasan yang telah diuraikan sebelumnya maka dapat disimpulkan yaitu sebagai berikut :
Pengaruh rekrutmen terhadap kinerja organisasi khususnya pada PT. Angkasa Pura I Bandar udara Hasanuddin Makassar yaitu Penyusunan strategi untuk merekrut termasuk dalam kategori sangat setuju dengan rata-rata skor dan ratarata persentase 3,32 atau 81,42 persen, Pencarian pelamar-pelamar kerja termasuk dalam kategori setuju dengan rata-rata skor dan rata-rata persentase 3,20 atau 75,5 persen. Penyisihan pelamar-pelamar kerja termasuk dalam kategori setuju dengan rata-rata skor 3,15 atau 78,75 persen. Pembuatan kumpulan pelamar termasuk dalam kategori setuju dengan rata-rata skor dan ratarata persentase 3,25 atau 60,25 persen.

\section{DAFTAR PUSTAKA}

Hasibuan, Malayu, SP. 2008. Manajemen Sumber Daya Manusia-edisi7 Jakarta: Bumi Aksara

Mathlis, 2001.Hiuman Resource Management (Manajemen Sumber Daya Manusia)Edisilo Jakarta: Salemba Empat 
Moekijat. 2010.Manajemen Sumber Daya Manusia.Cetakan kesembilan.Penerbit: Mandar Maju, Bandung

Nawawi. 2008. Manajemen umber daya manuia. PT gramedia widiasarana indonessia

Mangkunegara, 2006.Evaluasi kinerja sumber daya manuia.Jakarta :refika Aditama

Simamora, 1997.Manajemen sumber daya manusia.Yogyakarta : STIE YPKN

Sastrohadiwiryo, 2002.Manajemen tenaga kerja Indonesia. Bumi Aksara

Keban, 2004.Manajemen peronalia dan sumber daya manuia edisi kedua.Yogyakarta : BPFE

Furtwengler, 2002.Manajemen kinerja falsafah teori dan penerapannya. Jakarta: Pustaka pelajar

Dharma. 2002. Manajemen kinerja edisi ketiga. Yogyakrta : Pustaka Pelajar

Undang-Undang Republik Indonesia No 13 tahun 2014 tentang Ketenagakerjaan pasal 52 